
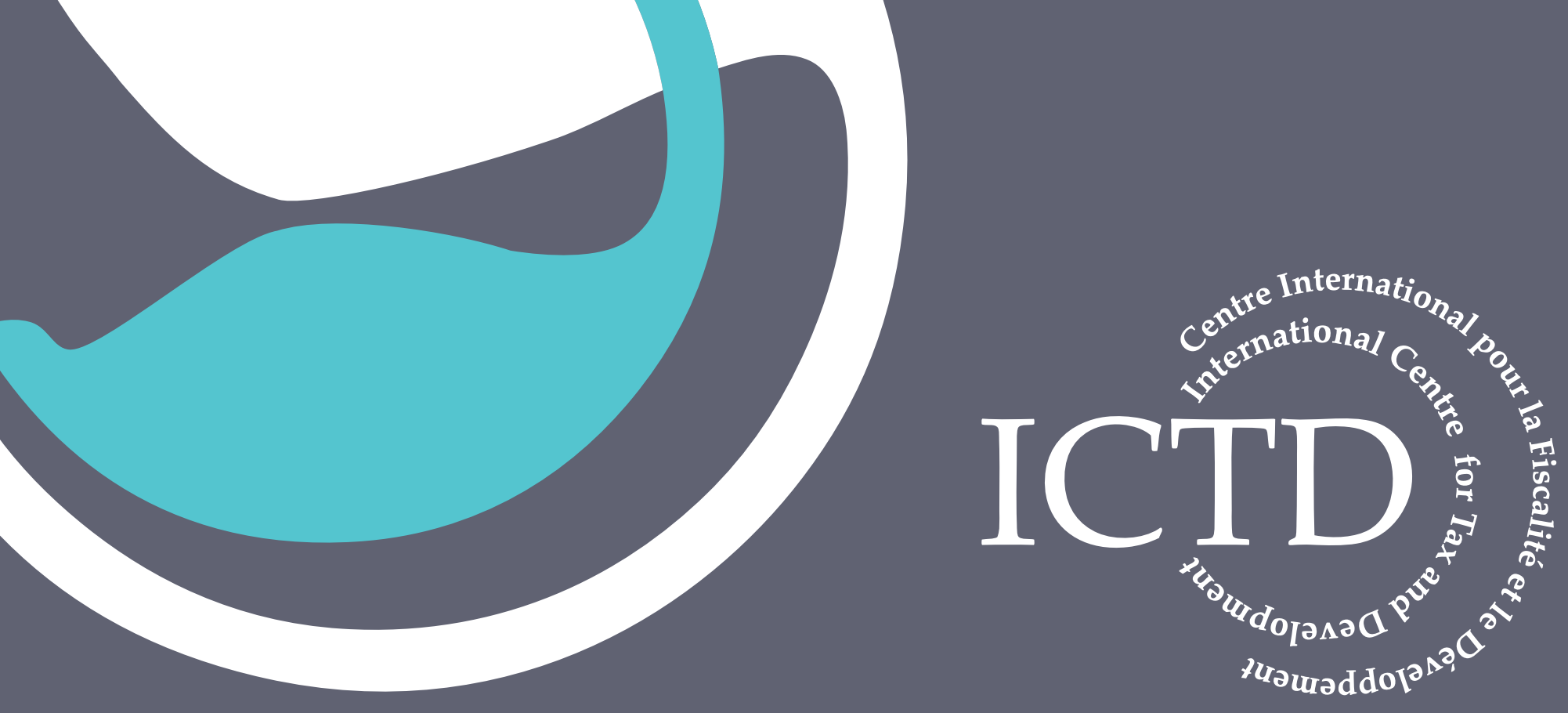

Working Paper 32

The Tax Policy Outlook for Developing Countries: Reflections on International Formulary Apportionment

Michael C. Durst

February 2015 
ICTD Working Paper 32

The Tax Policy Outlook for Developing Countries: Reflections on International Formulary Apportionment

Michael C. Durst

February 2015 
The Tax Policy Outlook for Developing Countries: Reflections on International Formulary Apportionment Michael C. Durst

ICTD Working Paper 32

First published by the Institute of Development Studies in February 2015

(c) Michael C. Durst 2015

ISBN: 978-1-78118-217-8

The author of this paper grants to the IDS and the ICTD a perpetual, irrevocable, worldwide, royalty-free, non-exclusive licence, or sublicence, to reproduce, communicate to the public, use, adapt, publish, distribute, display and transmit the work in any and all media, and to sublicense others (including the Crown) to reproduce, communicate to the public, use, adapt, publish, distribute, display and transmit the work in any and all media, for non-commercial purposes and with appropriate credit being given to the author and ICTD funders.

A catalogue record for this publication is available from the British Library.

This work has been licensed by the copyright holder for distribution in electronic format via any medium for the lifetime of the OpenDocs repository for the purpose of free access without charge and can be found at http://opendocs.ids.ac.uk/opendocs/

Also available from:

The International Centre for Tax and Development

at the Institute of Development Studies,

Brighton BN1 9RE, UK

Tel: +44 (0) 1273606261 Fax: +44 (0) 1273621202

E-mail: info@ictd.ac.uk

Web: www.ictd/en/publications

IDS is a charitable company limited by guarantee and registered in England (No. 877338) 


\title{
The Tax Policy Outlook for Developing Countries: Reflections on International Formulary Apportionment ${ }^{1}$
}

\author{
Michael C. Durst
}

\section{Summary}

The author offers a retrospective analysis of his recently-completed extensive research on the technical feasibility of international formulary apportionment of corporate taxable income, as a replacement for the body of 'arm's-length' transfer pricing rules generally in use around the world. In this retrospective analysis the author considers recent analytical work on base erosion and profit shifting (BEPS) conducted by the Organisation for Economic Cooperation and Development (OECD) as well as the International Monetary Fund (IMF). The author focuses especially on the needs of developing countries, which, because of problems associated with informal economic activity, need to rely more heavily on corporate income taxation than wealthier countries. The author generally agrees with the approach taken by both the OECD and IMF, which (i) would rely on targeted measures to curtail BEPS and would not seek to fully replace arm's-length rules with a formulary system, but (ii) would nevertheless incorporate elements of a formulary approach in order to remedy apparent defects in some important aspects of current arm's-length rules.

Keywords: transfer pricing; formulary apportionment; base erosion and profit shifting (BEPS); OECD; IMF.

Michael C. Durst is a long-time US tax practitioner, an author on international taxation and developing countries, a former government official and law professor, and an ICTD researcher. 


\section{Contents}

Summary 3

Acronyms $\quad 5$

Introduction $\quad 6$

$1 \quad$ The OECD and IMF analyses $\quad 7$

2 Perceived technical barriers to formulary apportionment 10

2.1 Concerns regarding double taxation 11

2.2 Problems with the sales factor 11

2.3 Tax treaty issues 13

2.4 Accounting barriers to formulary apportionment 14

$3 \quad$ High-priority measures for developing countries 15

3.1 Curbs on interest deductions 15

$\begin{array}{ll}3.2 \text { Hybrid transfer pricing methods } & 16\end{array}$

3.3 Excise taxes 18

4 Conclusion 18

$\begin{array}{ll}\text { References } & 20\end{array}$ 


\section{Acronyms}

$\begin{array}{ll}\text { APA } & \text { Advance Pricing Agreement } \\ \text { BEPS } & \text { Base Erosion and Profit Shifting } \\ \text { CCCTB } & \text { Common Consolidated Corporate Tax Base } \\ \text { CFC } & \text { Controlled Foreign Corporation } \\ \text { CPM } & \text { Comparable Profits Method } \\ \text { IMF } & \text { International Monetary Fund } \\ \text { NGO } & \text { Non-governmental organisation } \\ \text { OECD } & \text { Organisation for Economic Cooperation and Development } \\ \text { PE } & \text { Permanent Establishment } \\ \text { TNMM } & \text { Transactional Net Margin Method }\end{array}$




\section{Introduction}

A formulary system divides some of the income of a business group among tax jurisdictions according to the relative volume of the group's observable income-producing activities within those jurisdictions. Under formulary apportionment the income of a group is measured on an aggregate international basis, and is then divided among the different group members according to measures of their relative levels of economic activity, such as perhaps their relative level of sales. The formulary approach would substitute for the current practice of attempting to measure each entity's income on a separate accounting, or arm's-length, basis, an exercise which requires attempts to estimate arm's-length prices for the many transactions that typically occur among the different members of contemporary multinational groups.

The formulary principle may be implemented in many different ways. Versions of it are employed to allocate taxing rights over companies between the states of the United States and the provinces of Canada. The Canadian system generally divides companies' income among the provinces according to a two-factor formula. Equal weight is given to sales volumes and payroll expenses. The tax obligation of a company to any one provincial government is determined by the proportion of total company sales and payroll costs that is made in that province. The formulas historically employed by some US states involve sales, payroll expenses and the value of plant and equipment. Many US states now, though, use only a single factor - sales.

Any variant of formulary apportionment involves a degree of arbitrariness in the allocation of corporate income between the company and the tax collectors, and between different taxing jurisdictions. The core reason for considering a formulary approach is prevention of tax avoidance. Currently the complexity of arm's-length pricing has permitted many multinational groups to shift substantial amounts of taxable income through what the OECD has labelled 'base erosion and profit shifting' (BEPS), to zero- and low-tax countries where the multinationals conduct few if any business activities. Under a formulary system this would not be possible, as income could be apportioned only according to real and observable economic activities.

Apart from considerations of tax avoidance, a formulary system could remove a good deal of subjectivity from the workings of the international tax rules, thereby providing greater economic certainty to taxpayers and governments. Under the arm's-length transfer pricing rules now in use around the world, income is apportioned according to multinational groups' own estimates - which are subject to review upon examination by tax authorities - of the levels of income that would be earned by the different affiliates of commonly-controlled business groups if those affiliates were not commonly controlled, but instead operated in the manner of independent companies transacting with one another at arm's length. In practice under arm's-length transfer pricing rules groups estimate the proper division of income among their affiliates based on often-elaborate analyses by professional economists, according to the economists' perceptions of the different income-producing activities performed, assets owned, and business risks borne by the groups' affiliates in the countries in which the affiliates operate.

For about forty years, critics of the arm's-length approach have argued that it allows multinational taxpayers excessive flexibility to use networks of contracts made among group members to shift income from countries in which the groups conduct the bulk of their business activities to other affiliates established in zero- or low-tax countries, which often have few employees or sales and little if any plant and equipment. The contracts used to effect these shifts of income include licences for the use of intellectual property held by the zero- or low-tax affiliates, agreements for the lending of money, and various kinds of 
arrangements under which the low- or zero-tax affiliates are treated as bearing, in return for payment, group-wide business risks such as the risk of holding inventory located around the world.

A number of months have passed since I had the opportunity of publishing a multi-part analysis of the potential promises and limitations of the formulary system. ${ }^{2}$ As I was conducting my study the OECD, in coordination with the G20 group of countries, was beginning its extended and still ongoing study of BEPS, the shifting of income by multinational companies to zero- and low-tax countries. ${ }^{3}$ The OECD began its work in apparent response to a series of studies by non-governmental organisations (NGOs) and reports in newspapers and other media that claimed income-shifting had achieved very large proportions, and that substantial amounts of corporate tax revenue were apparently being removed annually from the tax jurisdiction of countries around the world in which multinational groups actually earn their incomes.

Base erosion and profit shifting removes corporate tax revenue from countries at all levels of economic development. The media reports that seem most directly to have triggered the OECD BEPS study focused on the transfer of revenue from Western European countries, and particularly the United Kingdom. ${ }^{4}$ Nevertheless, as several reports by NGOs have suggested, ${ }^{5}$ the practical consequences of base erosion seem to be greatest for the lowerincome developing countries. The wealthier countries of the world typically can collect government revenue relatively efficiently from domestic sources like personal income taxes and consumption taxes. The domestic economies of lower-income developing countries, however, often contain large informal sectors in which business is conducted at a very small scale with minimal books and records maintained. The lower-income countries therefore have a relatively greater financial stake than wealthier countries in successful action to control BEPS, at least until such time as they can better develop their domestic tax base.

Recognising the special importance to developing countries of efforts to control base erosion, in July and August 2014 the OECD issued a two-part Report to G20 Development Working Group on the Impact of BEPS in Low Income Countries (OECD 2014a, 2014b). The IMF, building on the OECD BEPS effort, has released a study on the same topic which the IMF describes as 'tax spillovers' of international tax rules as they affect developing countries (IMF 2014). The OECD and IMF reports provide a useful framework for considering both the potential benefits and limitations of formulary apportionment as a point of reference for designing international tax policies for the benefit of lower-income developing countries.

This paper: (i) summarises the potential benefits of and obstacles to formulary apportionment as a viable tax policy instrument for developing countries, and (ii) identifies high-priority topics for further research and analysis.

\section{The OECD and IMF analyses}

Perhaps the most striking element of the OECD's work on BEPS is the manner in which it articulates the root of the problem: the extent to which current tax laws permit members of multinational corporate groups to assign income to zero- or low-tax countries in which they

The eight instalments of the study were published by Bloomberg BNA (Durst 2014a, 2014b, 2014c, 2013a, 2013b, 2013c, 2013d, 2013e). Significant portions of these instalments benefited from generous research support from the International Centre for Tax and Development.

3 The OECD initiated its study with the Action Plan on Base Erosion and Profit Shifting (OECD 2013). The OECD's study continues at an intensive pace; results are shared at <http://www.oecd.org/ctp/beps.htm>.

e.g. Duncan and Cohen (2012) and Syal and Wintour (2012).

e.g. ActionAid (2012). 
conduct few if any business activities. In the words of the recent OECD report on BEPS and developing countries, base erosion results from 'arrangements that achieve no or low taxation by shifting profits away from the jurisdictions where the activities creating those profits take place' (OECD 2014a: 8). The key to curtailing BEPS therefore, in the words of another recent report from the G20 Group, is 'to put an end to the divorce between the location of profits and the location of real activities' (G20 2013: 4).

The language used by the OECD and G20 to describe the source of the BEPS problem evokes the central principle of formulary apportionment: income should be attributed for tax purposes to the locations where business activities are performed. Because formulary apportionment can apportion income only to places where real business activity takes place and in quantitative proportion to the extent of that activity, formulary apportionment would, if applied to a taxpayer's income from all sources, eliminate BEPS completely. That is, under a fully-implemented formulary system income could not simply be apportioned to countries where little if any economic activity is performed. At least in theory, therefore, formulary apportionment represents the most straightforward remedy for the BEPS problem.

The articulation by the OECD and G20 of the principle that the geographic distribution of taxable income should correspond to the locations of a taxpayer's activities helps to move the policy debate away from what historically has been a rather pointless ideological debate between proponents of arm's-length and formulary approaches. In light of the OECD/G20 analysis, there is no reason to think that the arm's-length and formulary approaches to the international division of taxable income rest on incompatible conceptual grounds.

The idea that the apportionment of income should follow the geographic locations of a taxpayer's activities can indeed be seen as an apt statement of the arm's-length principle, if the heart of that principle is seen as a rule of tax neutrality between the members of commonly-controlled corporate groups, and independent companies that must transact with one another at arm's length. Under long-standing principles of nexus in international tax law, legal entities are subject to tax in those jurisdictions where they are physically present and conduct their activities. ${ }^{6}$ It is impossible under this principle for a single independent legal entity to arrange for its income to be subject to tax in countries other than those where income-generating activities occur. This result can be achieved only by members of commonly-controlled corporate groups through the use of the kind of related-party contracts that stand at the heart of income-shifting transactions.

In short, by recommending an international tax system in which income is apportioned according to the geographic distribution of a taxpayer's business activities, the OECD is seeking to move international tax laws into greater conformity with the arm's-length standard. Moreover, at least in theory (an important caveat), formulary apportionment appears to offer a straightforward means of implementing the system the OECD wishes to bring about.

Despite the conceptual appeal of formulary apportionment in addressing BEPS, both the OECD and IMF have ruled out devoting substantial resources in the short term to an analysis of formulary apportionment as a replacement for the arm's-length principle. Both organisations attribute this decision to the presence of unanswered questions about the administrative feasibility of international formulary apportionment, as well as a formulary system's possible adverse effects on the share of the global tax base apportioned to developing countries. 
The OECD explains its conclusion as follows:

[A]doption of alternative transfer pricing methods like formulary apportionment would require development of a consensus on a number of key issues (which countries do not believe to be attainable in the short or medium term) and could also raise systemic problems which could result in even more damaging problems for countries' revenues. Accordingly, it is believed that it will be most productive to focus on addressing specific issues arising under the current arm's length system at the present time.

(OECD 2014c)

The IMF, for its part, explains:

Whatever its merits in principle, prospects for adoption of international [formulary apportionment] seem remote. A substantial legal and institutional infrastructure has been built around current arrangements, so that movement towards international [formulary apportionment] would likely involve considerable disruption. That might change if a major capital exporter were to move in that direction. But there is little immediate sign of that - with significant resistance within the EU, for instance, to the CCCTB [a pending European Union proposal for formulary apportionment to be applied regionally].

(IMF 2014: 41)

Rather than suggesting a formulary approach to combat BEPS, both the OECD and IMF recommend a combination of targeted anti-tax-avoidance measures that would involve, among other items:

(i) some modification of current arm's-length transfer pricing rules;

(ii) tightened rules to disallow deduction of interest expenses, especially when paid to related parties; and

(iii) strengthened controlled foreign corporation (CFC) rules, by which the home countries of multinational groups limit the amount of income that the groups are permitted to accumulate through their global operations in zero- or low-tax subsidiaries.

In addition the IMF notes that some elements of formulary apportionment might prove useful in efforts to modify current arm's-length pricing rules, with the particular goal of simplifying their application in the developing country setting. In particular the IMF suggests that some kinds of hybrid transfer pricing methods, perhaps including 'formulary profit split' methods, might be of practical benefit to developing countries (IMF 2014: 41-42).

In my view the OECD and IMF are prudent in refraining, at least at present, from encouraging substantial efforts to design and implement full-fledged formulary apportionment rules. As explored in my recently-published analysis (Durst 2014a, 2014b, 2014c, 2013a, 2013b, 2013c, 2013d, 2013e), significant technical and policy issues must be resolved before formulary apportionment can be implemented for international use. These questions cannot be resolved within the time frame in which BEPS should be curtailed, so focusing on other possible means of curtailing BEPS in the short term seems sensible.

Moreover, in addition to technical problems, international formulary apportionment faces a large political obstacle. For years business groups and legislators around the world have strenuously opposed replacing current transfer pricing rules with a formulary system, and there is no indication that this opposition is weakening. The political unpopularity of formulary apportionment probably arises at least in part from its most important potential benefit: a complete elimination of opportunities for BEPS. Businesses have a direct financial interest in discouraging formulary apportionment and in channelling political debate instead towards partial measures, that unlike formulary apportionment can form the basis of political 
compromise. Similarly, legislators - who have often displayed ambivalent attitudes towards corporate income taxation, especially in the international sphere - are likely to be more comfortable debating partial measures than the all-or-nothing remedy for BEPS that formulary apportionment represents. This tendency may well be present not only among legislators and other policymakers in the wealthier countries which are home to most of the multinationals that would see their tax burdens increase if BEPS were to be eliminated. In addition legislators and other policymakers in developing countries may be reluctant to entertain reforms that would entirely eliminate BEPS, out of fear that doing so could increase the after-tax costs of international business generally and discourage inbound investment to their country. In short, whatever its technical promise or limitations, international formulary apportionment, in part because of its potentially high degree of effectiveness in eliminating profit shifting, is a hard political sell in developing countries as well as the wealthier countries in which multinational groups tend to be based.

This situation could change over the long or even medium term. It is possible, for example, that some developing countries will perceive their need for additional corporate tax revenue to justify assembling a coalition to develop and adopt a formulary system. It is also possible that trends in tax reform around the world will lead to a global system in which statutory tax rates are significantly reduced and BEPS is no longer permitted to a significant extent, perhaps through global adoption of strengthened CFC rules. In that situation governments and businesses might both find formulary apportionment attractive for its predictability and administrative advantages. However neither of these situations appears likely to materialise in the immediate future.

Currently, therefore, the most useful application of technical insight into formulary apportionment, particularly from the standpoint of developing countries with their disproportionate dependence on corporate tax revenue, is to look for ideas that might be useful in designing incremental measures against base erosion, including hybrid transfer pricing methods as suggested by the IMF. The remainder of this paper seeks to promote this goal, first by summarising the primary conclusions concerning the promise and limitations of a formulary approach from my recently-published analysis, and then by suggesting some high-priority topics for follow-up research related to tax base protection for developing countries.

\section{Perceived technical barriers to formulary apportionment}

Historically debates over the feasibility of international formulary apportionment have focused primarily on four topics:

(i) the possibility that it would lead to double taxation, especially if different countries adopt inconsistent formulas;

(ii) difficulties associated with the sales factor in apportionment formulas, including both difficulties of tracking sales made in electronic commerce, and possible unfavourable treatment of developing countries if a formula weights the sales factor especially heavily as has occurred in apportionment among US states;

(iii) the perceived incompatibility of formulary apportionment with some elements of bilateral tax treaties; and

(iv) the arguable need for countries to adopt a common tax base to which countries' apportionment formulas would be applied. 


\subsection{Concerns regarding double taxation}

Opponents of formulary apportionment have often raised the concern that different countries would adopt differing apportionment formulas, just as the different US states have adopted a variety of different apportionment formulas for the purpose of domestic income apportionment within the US. This, critics contend, would cause double taxation and raise a barrier to cross-border investment.

Based on my recently-completed research, however, I am convinced - perhaps counterintuitively - that replacing arm's-length transfer pricing rules with formulary apportionment would in fact reduce instances of economically-damaging double taxation, even if different countries adopt inconsistent apportionment formulas. ${ }^{7}$ This is because under current arm'slength transfer pricing rules double taxation is unpredictable. Given the subjectivity of the current rules, tax authorities from two different countries often make overlapping claims to tax income from a taxpayer's cross-border investment, so that the taxpayer will end up paying total tax at an unexpectedly high overall effective rate. Moreover at the time a taxpayer must decide whether to make a particular cross-border investment, the taxpayer generally has no way of predicting the extent to which the tax authorities will make overlapping claims - a fact that infuses these decisions with additional risk.

A taxpayer facing the risk of what might turn out to be unacceptable levels of taxation will be less likely to make an investment than a taxpayer that is better able to predict the total effective rate at which the investment will be taxed. Currently, therefore, the unpredictability of the application in practice of today's arm's-length transfer pricing rules may significantly inhibit international investment. ${ }^{8}$

Under a formulary system, even if the two countries in which a taxpayer is considering investing apply inconsistent formulas, the investor generally will be able to predict in advance of the investment decision the effective rates at which each country will impose its tax. If the total effective rate is acceptable, the investor will proceed with the investment; if it is not, the taxpayer might seek more tax-friendly countries in which to invest. Most of the uncertainty generated by the arm's-length system will, however, be removed - a factor that should encourage cross-border investment generally.

In short it is not double taxation per se that raises barriers to international investment, but rather unpredictable double taxation. Formulary apportionment affords taxpayers greater certainty about the total effective tax rate than is available under arm's-length transfer pricing rules. Accordingly, and perhaps surprisingly, formulary apportionment is better suited to addressing economic damage from double taxation than arm's-length transfer pricing rules.

\subsection{Problems with the sales factor}

Over the past several decades US states have increasingly adopted single-factor apportionment formulas based on the destination of sales. ${ }^{9}$ The apparent reason for this movement has been tax competition. State governments have been concerned that apportioning income in part on other measures of economic activity, such as payroll or location of physical plant, discourages investment in employment or construction in the state.

This topic is addressed particularly in Durst (2013c). The discussion in that article is based on Durst (2012a) and Durst (2012b).

$8 \quad$ In some situations taxpayers may be able to mitigate the uncertainty raised by arm's-length pricing rules by obtaining advance pricing agreements (APAs) before making investments, or by obtaining relief from double taxation after the fact through competent authority negotiations conducted under bilateral tax treaties. However APAs are expensive and typically cannot be completed before investment decisions must be made; and competent authority negotiations can involve considerable expense and delay, are not always concluded successfully, and are unavailable in cases where the countries involved in particular cross-border transactions are not party to a bilateral tax treaty.

$9 \quad$ For historical discussion of formulary apportionment among the US states, see Durst (2013e). 
There is every reason to expect that under an international formulary apportionment system national governments would gravitate towards a sales-only apportionment formula as the US states have done. This prospect raises two different concerns:

(i) In an era of digital commerce it may be difficult to identify the destination of sales of various goods and services with sufficient reliability to support sales-based apportionment.

(ii) Sales-based apportionment might generate undesirable results for some countries, especially developing countries in which much income is generated by capital- or labourintensive activities, ranging from mineral extraction to providing outsourced business services.

The difficulty of determining the destination of sales in today's digitalised marketplace arises under both arm's-length and formulary systems. Both systems require determining the locations in which goods and services are ultimately consumed or otherwise used. Challenges arise mainly from three sources: (i) problems in tracing the identity of customers in electronic commerce; (ii) current permanent establishment rules, which generally do not treat the mere destination of sales as a basis for taxable nexus; and (iii) the ease with which taxpayers can route sales destined for high-tax countries through intermediaries in zero- or low-tax countries, thereby obscuring the locations in which products or services are actually consumed or used. The potential remedies for these difficulties generally are the same under both arm's-length and formulary systems. They are: (i) modifying nexus rules to allow salesdestination countries to assert claims to income arising from the sales; and (ii) evidentiary tests to reduce revenue losses from excessive attribution of sales to intermediaries in zeroor low-tax jurisdictions.

In the final instalment of my recently-completed study of formulary apportionment (Durst 2014a), I suggest an approach that might be used under formulary apportionment to address the problem of sales through zero- and low-tax intermediaries. Essentially the suggestion is that tax authorities generally accept without detailed examination attribution of sales to most jurisdictions, but where sales are attributed to zero- or low-tax countries taxpayers would be required to present clear evidence that the goods and services sold were actually used or consumed in those countries. This proposed solution is certainly not perfect. It could, however, lead to a tolerable level of compliance under a formulary system; indeed it might lead to fewer difficulties with respect to intermediary sales under a formulary system than currently are posed under arm's-length rules.

The additional concern, that apportionment based heavily on a sales factor might inappropriately reduce developing countries' share of the global tax base, is important to consider. The operations of multinational businesses in developing countries tend to focus especially heavily on large inputs of plant and equipment as in mineral extraction, or high personnel inputs as in the provision of outsourced services. Often, moreover, products manufactured in developing countries are exported, so they do not generate sales in the country for purposes of formulary apportionment. Other things being equal, therefore, apportionment based only or primarily on sales would appear to reduce developing countries' share of the global tax pie.

The concern that sales-based apportionment will operate adversely with respect to developing countries, however, rests on the implicit assumption that countries' tax rates must remain fixed at their current levels. If tax rates are held fixed, then an apportionment formula based only on sales would indeed be likely to generate lower tax revenue for many developing countries than a formula including as a factor either the value of physical plant or an indicator of local employment, or perhaps both. A country is not, however, required to maintain its tax rates at a constant level, so a country which stands to lose revenue as a 
result of a move to sales-based apportionment could make up the shortfall by increasing its rates.

Arguably, to apportion a corporate income tax on sales would cause the tax to resemble more closely a consumption tax, and therefore could place the economic burden of the tax more heavily on consumers than a corporate tax apportioned according to other factors. Although determining the ultimate incidence of different forms of tax raises complex questions, this concern may be valid. It should be borne in mind, however, that developing countries have a pressing need for more revenue than they are currently collecting; to the extent the needed revenue cannot be raised from corporate income tax it will need to be raised from other sources, unavoidably including consumption taxes. Therefore if salesbased apportionment constitutes the only realistic means of collecting higher corporate tax revenue, a move to sales-based apportionment may represent the most consumer-friendly policy despite the likelihood that some of the tax's incidence will fall on consumers.

\subsection{Tax treaty issues}

If formulary apportionment is to be implementable without the need for prohibitively complex accounting segmentations among taxpayers' different activities, individual national tax authorities should be permitted to apply their apportionment formulas to a comprehensive measure of the global combined income of each multinational group that has a member subject to tax within the country. ${ }^{10}$ The alternative would be to follow the practice that has arisen in the US, where nexus rules based on the US Constitution permit states to apply their apportionment formulas to only a portion of the taxpayer's nationwide combined income, namely the portion that arises from those particular business lines that have factual nexus with the particular state. ${ }^{11}$ For similar reasons investment income is not included in the combined income subject to apportionment, but is instead allocated to the taxpayer's home jurisdiction. The result is that formulary apportionment in the US often becomes embroiled in disruptive controversy concerning, for example, the boundaries of the particular unitary business that has nexus with a particular state, or the distinction between business and investment income. I conclude that countries adopting formulary apportionment would be well-advised to apply their formulas to all of a taxpayer's global income, from all sources.

This conclusion, however, raises difficulty under typical income tax treaties. They generally entitle countries to assert tax jurisdiction on legal entities operating within the country only with respect to income attributable to the entity's permanent establishment (PE) within the country, generally interpreted to mean a physical presence. This limitation might reasonably be interpreted as requiring that international formulary apportionment be limited by nexus rules similar to those that have been problematic in the US.

A related concern is that income tax treaties typically contain language suggesting that income must be apportioned among related legal entities as if they were independent parties transacting with one another at arm's length. It can reasonably be argued that apportioning a group's global combined income according to a formula would not meet this standard.

Accordingly, for formulary apportionment to be implemented efficiently on the basis of taxpayers' global combined income, international tax treaties may need to be modified or governments may need to be willing selectively to override the relevant provisions of their current tax treaties. Neither of these outcomes is likely unless strong global political support arises for formulary apportionment, and this seems unlikely in the near future. Therefore the provisions of current income tax treaties may add significantly to the barriers facing the

\footnotetext{
10 The accounting difficulties arising from attempts to apply formulary apportionment to only a portion of a taxpayer's combined global income are discussed in Durst (2013a, 2013b).

See Durst (2013d).
} 
adoption of international formulary apportionment, at least until current political alignments with respect to international taxation change markedly.

\subsection{Accounting barriers to formulary apportionment}

Formulary apportionment will place large and novel accounting demands on corporate taxpayers, as well as on the agencies that must audit their tax returns. These demands arise largely from the fact that each country has unique rules for translating taxpayers' 'book' (i.e. financial statement) income into taxable income. ${ }^{12}$ To determine a taxpayer's local taxable income, a national tax authority will need a measure of the taxpayer's global income - the income earned by the taxpayer from all sources around the world - that has been translated into taxable income according to the locally-applicable tax accounting rules. For example, if a taxpayer conducts business in ten different countries, and all of those countries have adopted formulary apportionment, the taxpayer might need to make ten separate translations of its global book income into taxable income under the different tax accounting rules of all ten countries.

This task is complicated by the fact that translating book into taxable income typically requires a detailed transaction-by-transaction look at the taxpayer's activities, since tax accounting rules are often activity-specific (e.g. requiring acceleration of income for long-term construction contracts, or mark-to-market accounting for some holdings of investment instruments).

The need for multiple book-to-tax translations might not be as prohibitive a barrier to formulary apportionment as it might initially appear to be. Multinational groups almost certainly already collect all the information necessary to accomplish the translations in their accounting databases; gearing up to conduct the translations therefore might amount primarily to an exercise in computer programming, albeit an expensive one. Although categorising some transactions under the applicable rules will require human judgment, the translation process should remain primarily electronic and over time companies would likely learn to accomplish the task reasonably smoothly. After companies surmount the learning curve, the cost of the accounting needed for formulary apportionment might end up being less than is now required to implement, document and defend a group's transfer pricing under arm's-length rules.

For the new accounting practices required for formulary apportionment to be developed, however, companies will need to commit willingly to the necessary work. A less-than-full commitment is likely to cause endless breakdowns in the accounting system and delays in successful implementation of the formulary system. Accordingly, the adoption of formulary apportionment on a widespread basis will probably need to wait until much greater support develops for it among business leaders.

An alternative means of dealing with the complexities of book-to-tax translations under formulary apportionment would be for the countries of the world to adopt a largely uniform tax base. Taxpayers doing business in multiple countries then generally would need to convert their combined global book income into taxable income only once, just as is required today in each country under arm's-length transfer pricing rules. Countries might even, in connection with the adoption of formulary apportionment, take the step of adopting book-tax conformity conforming their tax accounting rules to financial accounting rules - thereby achieving many simplifications to their tax systems in addition to smoothing the route to formulary apportionment. ${ }^{13}$

See the discussion of this topic in Durst (2013a).

For discussion of this topic, see Hanlon and Shevlin (2005). 
Substantially greater uniformity among countries' tax accounting systems - even to the point of book-tax conformity - seems politically unlikely unless a great deal of support arises around the world for a formulary apportionment regime. The many differences among contemporary tax accounting regimes have tended to arise from local political considerations, and might be politically quite difficult to modify. Moreover trying to establish a global norm for tax accounting might be perceived by some countries' governments as infringing on their flexibility in lawmaking, and even on national sovereignty.

In sum, of the major concerns typically raised against formulary apportionment, the need to simplify translations of book into tax income constitutes the largest practical impediment. The political will necessary to overcome this obstacle is not evident today, so the sensible course of action, as the OECD and IMF have advised, is to defer attempts to implement full-scale formulary apportionment and instead to draw on various potential remedies for BEPS, some of which are derived from principles of formulary apportionment, in order to assist countries in controlling base erosion within the overall framework of existing transfer pricing rules.

\section{High-priority measures for developing countries}

Summarised below are some measures that draw on apportionment concepts and might assist developing countries in curtailing revenue losses to BEPS in the short term. All of these measures have been mentioned in one form or another in the OECD's BEPS work and the IMF report on tax spillovers. The measures can be seen as providing a high-priority agenda for further research in the field of international taxation for developing countries.

\subsection{Curbs on interest deductions}

A large proportion of tax avoidance through base erosion relies on interest deductions on intra-group loans, with the interest often being paid directly or indirectly to affiliates in zero- or low-tax countries. In general, arm's-length transfer pricing rules are not designed to limit companies' ability to deduct interest paid to related parties. Transfer pricing rules typically are concerned with whether the interest rates charged on these loans exceed market rates, not whether there is a genuine business purpose for the related-party financing. Accordingly, measures in addition to improvements to the transfer pricing rules will be needed to curtail base erosion through interest payments.

Experience around the world suggests that even fairly simple limitations on interest deductibility might have material benefit. Currently, as part of its BEPS project, the OECD is engaged in an intensive study of possible best practice for limitations on interest deductions; the study seems geared towards identifying measures that should be of value to countries at varying stages of economic development (OECD 2014d). The OECD has emphasised that measures to limit interest deductions should be adopted by as wide a range of countries as possible in order to counteract the effect of tax competition, which historically appears to have inhibited countries from adopting effective deduction limitations on a unilateral basis OECD 2014d: 8). The approach being explored by the OECD has a number of what could be called formulary elements - deductions would be apportioned among entities based on either their relative value of assets or level of income. The OECD apparently is comfortable exploring a formulary approach in the limited context of interest apportionment because the accounting difficulties of the formulary approach, which the OECD discussion draft explores at length, should be more manageable in this context than in a more comprehensive regime of formulary apportionment. 


\subsection{Hybrid transfer pricing methods}

Currently transfer pricing practice around the world depends heavily on the OECD's transactional net margin method (TNMM), generally referred to as the comparable profits method (CPM) under US practice. In a TNMM analysis the net income of a taxpayer affiliate in a particular country is supposed to be benchmarked against that of comparable companies which are not themselves part of multinational groups, operating in the same markets. Consider, for example, Distribco - a soft drink distributor that is part of a multinational group with a parent in Northland - which distributes beverages in Southland, a developing country. Distribco pays a royalty for using the group's trademark to an intangibles holding company that the group maintains in a zero-tax country. Under TNMM the tax authority of Southland is supposed to compare the profitability of the distributor, after paying the royalty, against the profitability of independent distributors of soft drinks (or perhaps similar products) that also operate in Southland. If the taxpayer's income in Southland is at least as high as that of the identified comparables, the taxpayer's transfer pricing results are accepted as arm's-length.

Based on my experience with TNMM, I believe its widespread use is largely attributable to the appearance of scientific precision provided by the computerised nature of the TNMM analysis. In many cases, however, using TNMM is conceptually inappropriate and effectively permits large amounts of profit shifting.

Where TNMM provides inappropriate results, the failure is usually attributable to either or both of the two factors mentioned above. First, the method is based on the implicit assumption that the local affiliate of a multinational group typically could expect at arm's length to earn only a limited routine return from its activities. For example, TNMM incorporates the implicit assumption that the local distributor of a multinational group's products is entitled merely to compensation for the bare services of taking orders and delivering products to buyers. Any additional income earned from sales of the products in the particular market is assumed typically to be attributable to brand volume that the parent group has built, and is allowed to be compensated by royalties. Similarly, when TNMM historically has been applied to developing country manufacturing and service operations of a multinational group, the practice has been to reject implicitly the idea that special features of the local consumer or labour market that might be seen as increasing the multinational group's profitability in the market - such as the presence of rapidly-increasing consumer demand (sometimes called a market intangible) or the availability of a highly productive work force at relatively low rates of compensation (sometimes called location savings) - should be seen as income of the local affiliate of the group rather than the group's parent. The tax authorities of some developing countries, particularly the most economically powerful ones, are challenging the practice of treating income from market intangibles and location savings in this manner, but still around the world taxpayers typically apply TNMM to minimise the income that is attributable to local subsidiaries, and therefore to maximise the amount of income that can be shifted away from local subsidiaries through various kinds of relatedparty payments.

A second problem with TNMM, especially as the method is applied in developing countries, is that information on 'uncontrolled comparables' that would be necessary to apply the method effectively is often not available. First, multinational groups often conduct activities that are significantly different - in scale as well as the level of risk involved - from those conducted by independent companies. Second, the stock of many independent companies is not publicly traded, so their financial data is not contained in the commercially-available databases. The result is that the typical transfer pricing analysis under TNMM relies on small sample sizes from inexact comparables. The sample sizes are too small to permit valid statistical analysis, and the ranges of results (usually in practice based on the interquartile range between the $25^{\text {th }}$ and $75^{\text {th }}$ percentiles of the data) are, in the author's experience, too wide to be of much use in tax administration. For example, a typical TNMM analysis might 
suggest that the arm's-length profit margin for a distributor in a particular country extends from 1 per cent to 3 per cent. This means that a distributor with a sales volume of, say, $\$ 10$ million will be considered to comply with the arm's-length principle if it earns anywhere from $\$ 100,000$ to $\$ 400,000$ per year - a range of uncertainty far too wide to support credible tax enforcement. $^{14}$

In short, the practical value in tax administration of TNMM based on searches of publiclyavailable financial data is considerably less than is sometimes thought. Given its relative simplicity, TNMM may be appropriate for identifying large income understatements by small local affiliates of multinational groups performing relatively simple kinds of business activities. In more demanding situations, however, developing countries will need to use methods that offer the relative simplicity of TNMM, but are capable of producing more economicallyrealistic results.

Of the transfer pricing methods currently in use around the world the most obvious candidate is the profit split method, under which income from a particular economic activity of a multinational group is divided among group members according to their relative contribution to the group's activity. More frequent use of profit split methods might benefit developing countries, allowing them both to avoid searches for comparables and to establish the case for greater margins being attributed to operations in their countries, thereby reducing revenue losses from profit shifting.

A number of different kinds of profit split method are currently used around the world.$^{15}$ The type of profit split likely to be most useful to developing countries is the overall profit split, sometimes called the contribution-analysis profit split, in which profits are divided in a onestep process among participants based on their relative contributions. This contrasts with the residual profit split, in which as a first step TNMM returns are assigned to participants' perceived routine activities, and then the remaining profit is divided based on relative contributions. The residual approach involves relying to some extent on comparables data, and also involves the difficult task of separating group members' activities into routine and non-routine components. An overall profit split, on the other hand, does not require identifying comparables, nor does it require trying to distinguish between routine and nonroutine activities.

For overall profit splits to serve as the workhorse of developing country transfer pricing regimes, however, it will be necessary to solve two important problems that historically have hampered the application of profit splits. First, the OECD Guidelines, perhaps seeking to avoid the perception of endorsing a formulary approach, state strongly that profit splits must be designed on a case-by-case basis, according to a detailed economic analysis of each taxpayer's facts and circumstances. Although perhaps appealing in theory, this individualised approach lends substantial subjectivity and unpredictability to the design of profit splits and also requires expenditure of time and resources, by taxpayers and tax administrations alike, which are disproportionate to any degree of persuasiveness actually added to the method by the extended economic analysis. This difficulty is likely to be especially severe in the resource-limited context of developing country tax administration. As a practical matter, if the profit split method is to be used reasonably efficiently by developing country tax administrations, some level of uniformity will need to be tolerated in the application of the method to different taxpayers operating in the same industry.

In addition, for profit splits to be effective in controlling base erosion, they will need to apportion income to different parties not according to the parties' mere levels of expenditure

This statistical phenomenon is discussed in Durst (2013c) and in Durst and Culbertson (2003).

The various profit splits in use today are described in the OECD Transfer Pricing Guidelines for Multinational Enterprises and Tax Administrations (OECD n.d.), beginning with paragraph 2.118. 
in supporting the group's income-producing activities, but instead according to the business activities actually performed by the parties. In practice many profit splits have apportioned income according to the parties' mere expenditure of cash, and therefore have contributed to the proliferation of BEPS transactions. It will be necessary to change this practice if profit splits are to be useful as a tool against BEPS - but the change will be perceived as a substantial one and is bound to elicit political opposition.

In short, designing a hybrid transfer pricing method for use by developing countries in addressing BEPS will require significant modification of both the TNMM and profit split paradigms under existing transfer pricing methods. ${ }^{16}$ It is to be hoped that the IMF, OECD and other expert bodies will continue to address this issue as their BEPS-related work proceeds.

\subsection{Excise taxes}

For some complex industries, the complexity of the transfer pricing rules will almost certainly exceed the enforcement capacities of national tax administrations. For example, telecommunications carriers, including cellular service providers, engage in a virtually untraceable network of transactions with related and unrelated parties for roaming services and call completion and origination. Similarly banks and insurance companies engage in such large volumes of related-party transactions - such as loans, derivatives transactions and reinsurance arrangements - that transfer pricing analysis is effectively impossible. Even local distribution, manufacturing and service-provider affiliates of multinational groups, whose transactions are less complicated, present a challenge because they are numerous and it is difficult to locate appropriate comparables. For these circumstances countries may wish to consider an excise tax in place of a corporate income tax. ${ }^{17}$

Telecom providers, banks and insurance companies, for example, might be exempted from income taxation in return for increases in existing excise taxes on telecoms charges, bank fees and insurance premiums. In addition, a country might impose a small excise tax on manufactured and distributed products in lieu of an income tax on taxpayers that are engaged only in manufacturing or distribution activities. Designing and implementing excise taxes will require careful analysis and drafting, but the basic structural elements of excise taxes are well known around the world. Administration of these taxes would require only measurement of local sales revenue; the remainder of the extensive fact-finding and detailed economic analysis currently required under transfer pricing rules generally should not be necessary. It seems likely that substituting excise for income taxes in some situations where income tax administration is especially problematic could assist developing countries in raising increased revenue at relatively modest administrative expense.

\section{Conclusion}

In the course of their recent work, both the OECD and IMF have accurately pointed to unresolved deficiencies in today's arm's-length transfer pricing rules, including the tendency of those rules, as they have historically been applied, to enable profit shifting. Successfully Implemented, international formulary apportionment could largely curtail BEPS. However a formulary system is not feasible in the near future owing to unresolved technical questions and strong political opposition. For the present, developing countries and the international agencies that advise them should consider measures to:

\footnotetext{
16 For one suggested approach see the author's suggestion for fashioning a transfer pricing method using the format of TNMM, but basing the method on group rather than separate entity profitability, in Durst (2015). See Durst (2014d).
} 
(i) effectively limit related-party interest deductions;

(ii) develop more effective transfer pricing methods under the arm's-length paradigm; and

(iii) supplement excise taxes for corporate income taxation where effective transfer pricing enforcement is highly impracticable.

These tasks raise significant technical as well as political challenges. Solving them will require considerable international cooperation, including the involvement of groups such as the IMF, World Bank and OECD. In addition developing country governments will need to generate the political will to implement these and other means of protecting their tax bases against erosion, notwithstanding the political pressures of tax competition; and multinational businesses and their home-country governments will need to exercise political and economic restraint and limit opposition to developing countries' efforts to increase their tax collection on income from inbound investment, at least until such time as the developing countries are in a better position to raise needed revenue from domestic sources. 


\section{References}

ActionAid (2012) Calling Time: Why SABMiller Should Stop Dodging Taxes in Africa, ActionAid (updated version, April 2012)

Duncan, H. and Cohen, T. (2012) 'Starbucks "Treats Tax Like a Church Collection Plate": Treasury Chief Secretary Attacks Coffee Chain', Daily Mail, 9 December 2012

Durst, M. (2015) 'Developing Country Taxation, Part V: Designing a Hybrid Transfer Pricing Method', Bloomsberg BNA Tax Management Transfer Pricing Report 23(18), 22 January 2015

- (2014a) 'Analysis of a Formulary System, Part VIII: Suggested Statutory, Regulatory Language for Implementing Formulary Apportionment', Bloomsberg BNA Tax Management Transfer Pricing Report 23: 70, 1 May 2014

_ (2014b) 'Analysis of a Formulary System, Part VII: The Sales Factor', Bloomsberg BNA Tax Management Transfer Pricing Report 22(22): 1414, 20 March 2014

— (2014c) 'Analysis of a Formulary System, Part VI: Building the Formula', Bloomsberg BNA Tax Management Transfer Pricing Report 22(18): 1180, 23 January 2014

- (2014d) 'Developing Country Taxation, Part II: The Limits of Corporate Income Taxation', Bloomsberg BNA Tax Management Transfer Pricing Report, 10 July 2014

- (2013a) 'Analysis of a Formulary System, Part V: Apportionment Using a Combined Tax Base', Bloomsberg BNA Tax Management Transfer Pricing Report 22(15): 972, 28 November 2013

— (2013b) 'Analysis of a Formulary System, Part IV: Choosing a Tax Base', Bloomsberg BNA Tax Management Transfer Pricing Report 22(12): 771-775, 17 October 2013

- (2013c) 'Analysis of a Formulary System for Dividing Income, Part III: Comparative Assessment of Formulary, Arm's Length Regimes', Bloomsberg BNA Tax Management Transfer Pricing Report 22: 653, 5 September 2013

— (2013d) 'Analysis of a Formulary System for Dividing Income, Part II: Examining Current Formulary and Arm's Length Approaches', Bloomsberg BNA Tax Management Transfer Pricing Report 22(5): 270, 27 June 2013

- (2013e) 'Starting the Conversation: A Formulary System for Dividing Income Among Taxing Jurisdictions', Bloomsberg BNA Tax Management Transfer Pricing Report, 22(2): 98, 16 May 2013

_ (2012a) 'Untangling Double Taxation in Transfer Pricing Policymaking', Tax Notes 1689, 26 March 2012

— (2012b) 'Transfer Pricing and Double Tax: Rethinking Conventional Wisdom', Tax Notes 551-556, 29 October 2012 
_ and Culbertson, R. (2003) 'Clearing Away the Sand: Retrospective Methods and Prospective Documentation in Transfer Pricing Today', Tax Law Review 57: 37-84

Hanlon, M. and Shevlin, T. (2005) 'Book-Tax Conformity for Corporate Income: An Introduction to the Issues', in J. Poterba (ed), Tax Policy and the Economy 19, National Bureau of Economic Research, Cambridge MA: MIT Press

G20 (2013) Tax Annex to the Saint Petersburg G20 Leaders' Declaration (September 2013)

IMF (2014) Spillovers in International Corporate Taxation, IMF Policy Paper, 9 May 2014, Washington DC: International Monetary Fund, available at <http://www.imf.org/external/np/pp/eng/2014/050914.pdf>

OECD (2014a) Part 1 of a Report to G20 Development Working Group on the Impact of BEPS in Low Income Countries, OECD, available at <http://www.oecd.org/tax/part-1of-report-to-g20-dwg-on-the-impact-of-beps-in-low-income-countries.pdf>

- (2014b) Part 2 of a Report to G20 Development Working Group on the Impact of BEPS in Low Income Countries, OECD, available at

$<$ http://www.oecd.org/g20/topics/taxation/part-2-of-report-to-g20-dwg-on-the-impact-ofbeps-in-low-income-countries.pdf>

- (2014c) BEPS - Frequently Asked Questions (16 October 2014), available at <http://www.oecd.org/ctp/beps-frequentlyaskedquestions.htm>

- (2014d) BEPS Action 4: Interest Deductions and Other Financial Payments, Public Discussion Draft 18 December 2014-6 February 2015, OECD

_ (2013) Action Plan on Base Erosion and Profit Shifting, OECD Publishing

_ (n.d.) Transfer Pricing Guidelines for Multinational Enterprises and Tax Administrations, OECD

Syal, R. and Wintour, P. (2012) 'MPs Attack Amazon, Google and Starbucks', The Guardian, 2 December 2012 


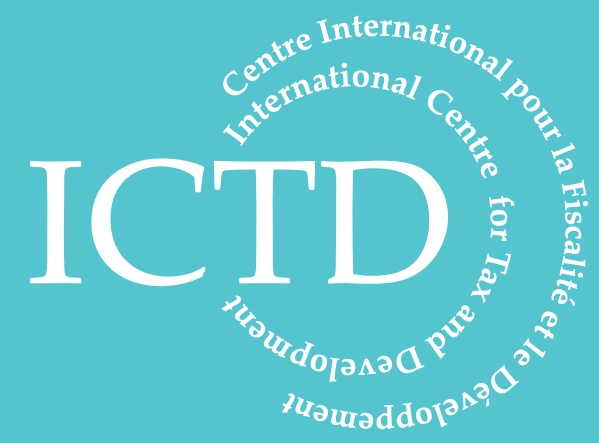

International Centre for Tax and Development at the Institute of Development Studies

Brighton BN1 9RE, UK

T: +44 (0) 1273606261

F: $+44(0) 1273621202$

E: info@ictd.ac

www.ictd.ac 